\title{
Mouse Models for Pendrin-Associated Loss of Cochlear and Vestibular Function
}

\author{
Philine Wangemann \\ Anatomy \& Physiology Department, Kansas State University, Manhattan, Kansas, USA
}

\section{Key Words}

Slc26a4 • Enlarged vestibular aqueduct - Hearing - Cochlea • Endolymphatic sac • Genetic disease model

\begin{abstract}
The human gene SLC26A4 and the mouse ortholog Slc26a4 code for the protein pendrin, which is an anion exchanger expressed in apical membranes of selected epithelia. In the inner ear, pendrin is expressed in the cochlea, the vestibular labyrinth and the endolymphatic sac. Lossof-function and hypo-functional mutations cause an enlargement of the vestibular aqueduct (EVA) and sensorineural hearing loss. The relatively high prevalence of SLC26A4 mutations provides a strong imperative to develop rational interventions that delay, ameliorate or prevent pendrin-associated loss of cochlear and vestibular function. This review summarizes recent studies in mouse models that have been developed to delineate the role of pendrin in the physiology of hearing and balance and that have brought forward the concept that a temporally and spatially limited therapy may be sufficient to secure a life-time of normal hearing in children bearing mutations of SLC26A4.
\end{abstract}

Copyright $@ 2013$ S. Karger AG, Basel

\section{Introduction}

The gene SLC26A4 (MIM \#605646) codes for the protein pendrin, which is an electroneutral exchanger for anions such as $\mathrm{HCO}_{3}{ }^{-}, \mathrm{Cl}^{-}$, and $\mathrm{I}^{-}$[1-3]. Pendrin is predominantly expressed in epithelial cells of the inner ear, the thyroid, and the kidney but has also been found in airways, mammary gland and liver [4-10]. 
The expression of SLC26A4 in the inner ear and the thyroid is consistent with the observation that mutations of SLC26A4 (MIM \#605646) cause congenital hearing loss associated with an enlarged vestibular aqueduct (EVA; MIM \#600791) and Mondini-like dysplasia of the cochlea and enlargement of the thyroid (Pendred syndrome; MIM \#274600). Hearing loss is typically progressive, often fluctuating, and occurs with an onset before or around the time of speech and language acquisition $[11,12]$. Vestibular deficits are less overt [13-16].

The prevalence and the spectra of SLC26A4 mutations vary among populations. Mutations have been reported to occur in $5.6 \%, 5-10 \%$, or $13.7 \%$ of children with congenital hearing loss [17-19]. The relatively high prevalence provides an imperative to investigate the etiology of SLC26A4-related deafness with the ultimate goal to develop strategies to preserve hearing in affected individuals.

This review provides a brief summary of recent studies in mouse models that have been developed to delineate the role of pendrin in the physiology of hearing and balance. Clinical phenotypes, the genetics of hearing loss associated with an enlargement of the vestibular aqueduct and more details on the development of the murine inner ear are reviewed elsewhere [20-22].

\section{Development of the murine inner ear}

The development of the inner ear begins in mice at embryonic day 9.5 (E9.5) with the formation of an otocyst [23]. The otocyst encloses amniotic fluid, which is a plasma-like fluid containing $\sim 140 \mathrm{mM} \mathrm{Na}^{+}$and $\sim 10 \mathrm{mM} \mathrm{K}^{+}$[24]. Between E10 and E10.5, two protrusions begin to extend from the otocyst; one forms the cochlea and the other forms the endolymphatic sac. While the protrusions elongate, the center of the otocyst reorganizes into the vestibular labyrinth. The lumen of the endolymphatic sac opens at E10.5 and the lumen of the cochlea opens at E14.5 [25]. Lumen formation during the growth phase of the inner ear is controlled by a balance of fluid secretion and absorption. Fluid secretion appears to occur in the vestibular labyrinth and fluid absorption in the endolymphatic sac [25]. The hypothesis that $\mathrm{Cl}^{-}$secretion and $\mathrm{Na}^{+}$absorption control luminal volume during the growth phase of the inner ear is consistent with the finding that the epithelial lumen of the cochlea and the endolymphatic sac is filled until E17.5 with a solution that contains $\sim 140$ $\mathrm{mM} \mathrm{Na}^{+}, \sim 126 \mathrm{mM} \mathrm{Cl}^{-} \sim 10 \mathrm{mM} \mathrm{K}^{+}$, and $\sim 25 \mathrm{mM} \mathrm{HCO}_{3}^{-}$[26].

At E17.5 the interconnected fluid compartments of the inner ear separate into two systems [27]. One system consists of the utricle, three ampullae and three semicircular canals and the other of the cochlea, the saccule and the endolymphatic sac. Vestibular sensory cells acquire mechanosensitivity at E17 [28, 29]. The onset of vestibular function is $\sim 8$ days later, at postnatal day 4 ( $\mathrm{P} 4)$, concurrent with the general maturation of the organ and the maturation of the innervation [30,31]. Cochlear sensory cells acquire mature mechanosensitivity at P0 [29]. The onset of hearing is $~ 12$ days later, at P12, concurrent with the development of the endocochlear potential, which rises between P5 and P15 from $\sim 10 \mathrm{mV}$ to the mature voltage of $\sim 90 \mathrm{mV}$ [32-34].

With the conclusion of the growth phase of the cochlea, the luminal fluid, endolymph, changes from a $\mathrm{NaCl}$ to a $\mathrm{KCl}$ solution. The onset of $\mathrm{K}^{+}$secretion is at E19.5 [26]. Two days later, at postnatal day 0 , cochlear endolymph already contains $\sim 70 \mathrm{mM} \mathrm{K}^{+}$and 5 days later, at $\mathrm{P} 3$, endolymph contains $\sim 100 \mathrm{mM} \mathrm{K}^{+}$, which is close to the mature concentration of $150 \mathrm{mM}$ $\mathrm{K}^{+}$[26]. The rise of the $\mathrm{K}^{+}$concentration is paralleled by a decline of the $\mathrm{Na}^{+}$concentration [26]. In the mature inner ear, the $\mathrm{Na}^{+}$concentration amounts to $1 \mathrm{mM}$ and the $\mathrm{Ca}^{2+}$ concentration to $22 \mu \mathrm{M}$, both concentrations being unusually low for an extracellular fluid [35]. 


\section{Pendrin expression in the inner ear}

In the mature inner ear, pendrin is expressed in the apical membrane of non-sensory epithelial cells in the cochlea, the vestibular labyrinth and the endolymphatic sac [6, 36]. During development, the earliest expression in the inner ear occurs at E11.5 in the endolymphatic sac [37]. Between E13.5 and E14.5, expression in the endolymphatic sac surges dramatically, and virtually all pendrin expression in the E14.5 inner ear is located in the endolymphatic sac. In the cochlea, the earliest expression of pendrin is found in the hook region at E14.5. Between E14.5 and E17.5, pendrin expression expands from the hook region to the lower and then to the upper turn of the cochlea. The onset of pendrin expression in the vestibular labyrinth occurs at E16.5. Pendrin in the inner ear functions mainly as a $\mathrm{Cl}^{-} / \mathrm{HCO}_{3}$ exchanger which secretes $\mathrm{HCO}_{3}{ }^{-}$into endolymph and thereby elevates the endolymphatic $\mathrm{pH}$ $[34,37,38]$.

\section{Development of the inner ear without pendrin}

The first mouse model, Slc26a4 ${ }^{\Delta / \Delta}$, formerly called Slc26a4\% or $P d s^{\%}$, is a knock-out in which exon 8 of Slc26a4 is replaced with a neomycin cassette [39]. The replacement introduces a frame shift, which prevents the generation of a functional protein. As in many patients with bi-allelic mutations, Slc26a ${ }^{\Delta / \Delta}$ mice develop an enlarged vestibular aqueduct and a Mondini-like dysplasia of the cochlea. Slc26a4 $4 / \Delta$ mice fail to develop hearing and display circling and head bobbing behavior consistent with an overt vestibular defect. The hearing and balance phenotype of Slc26a4 $4^{\Delta / \Delta}$ mice is more severe than the phenotype in most patients, who are born with residual hearing. Consistent with the recessive inheritance pattern, Slc26a $4^{\Delta /+}$ mice develop normal sensory systems and normal hearing and balance. Slc26a4 $4^{\Delta / \Delta}$ and Slc26a $4^{\Delta /+}$ mice have been used extensively to investigate the consequence of a complete lack of pendrin for the development of the inner ear $[6,25,26,34,37,38,40$ 43]. Several phenotypic features of Slc2 $6 a 4^{\Delta / \Delta}$ mice are also observed in a knock-in mouse in which a splice-site mutation is introduced at exon 8 of Slc26a4 to introduce a frame-shift and a new stop-codon [44].

The first pathobiological alteration of the inner ear of Slc26a $4^{\Delta / \Delta}$ mice is the enlargement of the luminal volume that begins at E14.5 and coincides with cochlear lumen formation $[37,39]$. This enlargement appears to be the consequence of an imbalance between fluid secretion and fluid absorption during the growth phase of the inner ear. At E18.5, when the growth phase of the inner ear ends, the enlargement amounts to a 10-fold larger volume of scala media in the cochlea of Slc26a $4^{\Delta / \Delta}$ mice compared to Slc26a $4^{\Delta /+}$ mice. This enlargement persists throughout adulthood.

The second pathobiological alteration in the inner ear of Slc26a4 $4^{\Delta / \Delta}$ mice is the acidification of cochlear endolymph that develops at E15.5 and coincides which the failed onset of pendrin expression [37]. Acidification of the luminal fluid also occurs in the endolymphatic sac and has been documented in the mature inner ear in the cochlea and the utricle of the vestibular labyrinth $[34,38]$.

Luminal enlargement and acidification are the primary pathobiological alterations, which distribute the effect of pendrin deficiency from pendrin-expressing cells to the entire inner ear [25]. Luminal acidification alters $\mathrm{pH}$-sensitive mechanisms and luminal enlargement limits cell-to-cell communication mechanisms that rely on diffusible factors transmitted via the luminal or abluminal compartment. Impaired cell-to-cell communication may be responsible for the premature onset of connexin 26 expression in basal cells of stria vascularis at E18.5, for the retarded development of the layered structure of stria vascularis at P3 and the retarded development and delayed innervation of the organ of Corti that manifests as a local hypothyroidism between P5-P10 [37, 43].

A remarkable number of secondary consequences of the lack of pendrin expression in the cochlea have been observed and include an increase in the rate of $\mathrm{K}^{+}$secretion by 


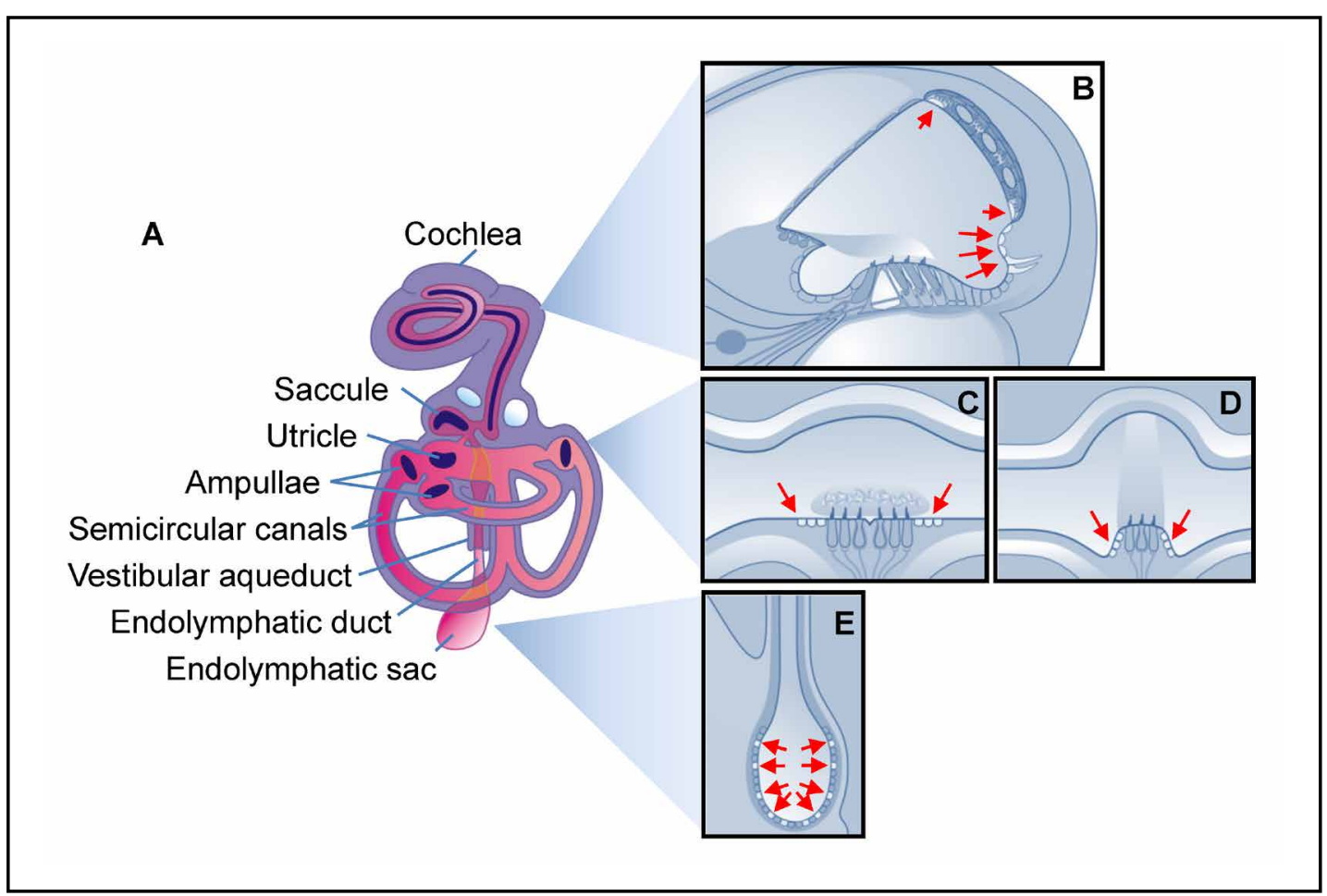

Fig. 1. Pendrin expression in the inner ear. A) The inner ear consists of six sensory organs including the cochlea for hearing, the saccule and utricle for sensing linear acceleration and three ampullae and semicircular canals for sensing angular acceleration. In addition, the inner ear contains a non-sensory structure, the endolymphatic duct and sac. All compartments of the inner ear are lined with epithelial cells and filled with endolymph. The epithelial compartments in the cochlea, utricle and saccule, ampullae and semicircular canals are surrounded by perilymph and epithelial compartment of the endolymphatic sac is surrounded by cerebrospinal fluid. B) Cross-section of one turn of the cochlea. The depicted morphology represents the mature stage of development which is acquired in mice during the second postnatal week. Pendrin is expressed in epithelial cells of the spiral prominence (long arrows) and in spindle cells of stria vascularis (short arrows). C-D) Cross-sections of the saccule or utricle and an ampulla. Pendrin is expressed in transitional cells, which are epithelial cells surrounding the maculae in the saccule and utricle and the cupulae in the ampullae. Transitional cells are engaged in cation absorption. E) Cross-sections of the endolymphatic duct and sac. The depicted simple morphology of the endolymphatic sac represents the late phase of embryonic development in the mouse. During the early postnatal period of development, the morphology of the endolymphatic sac becomes more complex with epithelial ridges and tubular infoldings. The endolymphatic duct penetrates through a canal in the bone, which is called the vestibular aqueduct. Pendrin is most prominently expressed in the apical membrane of mitochondria-rich cells in the endolymphatic sac (arrows). A similar diagram was contributed by the author to another paper [52].

strial marginal cells, oxidative and nitrative stress in stria vascularis, a loss of the $\mathrm{K}^{+}$channel KCNJ10 in intermediate cells, a loss of the endocochlear potential, a rise in the endolymphatic $\mathrm{Ca}^{2+}$ concentration, and finally a degeneration of sensory cells and stria vascularis $[6,26,34$, $40,41]$. The increase in the rate of $\mathrm{K}^{+}$secretion is evident from the finding that differences in endolymph $\mathrm{K}^{+}$concentrations between Slc26a $4^{\Delta / \Delta}$ and Slc26a4 ${ }^{\Delta /+}$ mice never exceed a factor of 2 , while the volume of endolymph differed by a factor of $10[25,26]$. Whether the increase in the rate of $\mathrm{K}^{+}$secretion is a function of the enlarged luminal volume or a function of the lower $\mathrm{pH}$ is unknown. Marginal cells measure $\mathrm{K}^{+}$concentrations at the apical membrane by an unknown mechanism and low apical $\mathrm{K}^{+}$concentrations lead to an increase in the rate of $\mathrm{K}^{+}$ secretion $[45,46]$. A pH effect on $\mathrm{K}^{+}$secretion is also conceivable since the $\mathrm{K}^{+}$channel KCNQ1 in the apical membrane of marginal cells is activated by extracellular acidification [47]. 
Oxidative and nitrative stress is evident from the presence of elevated amounts of nitrated and oxidized proteins in stria vascularis of Slc26a4 $4^{\Delta / \Delta}$ mice [41]. Oxidative and nitrative stress may be the consequence of higher metabolic rates necessary to maintain higher rates of $\mathrm{K}^{+}$secretion or the consequence of increased free radical production independent of ion transport possibly in the presence of incompletely developed free-radical defense mechanisms. The expression of the $\mathrm{K}^{+}$channel KCNJ10 has been shown to be sensitive to the combination of oxidative and nitrative stress [41]. Loss of KCNJ10 expression is sufficient to abolish the endocochlear potential [48]. It is not known whether tight junctions, which are required for the generation of the endocochlear potential, are compromised by cell stretching and acidification, nor is it known whether junctional compromise contributes to the loss of the endocochlear potential.

Acidification of endolymph is likely a major factor contributing to the elevation of the endolymphatic $\mathrm{Ca}^{2+}$ concentration since cochlear epithelial cells express the acid-sensitive $\mathrm{Ca}^{2+}$ channels Trpv5 and Trpv6 [34]. The concentration of $\mathrm{Ca}^{2+}$ in endolymph of normal mice, such as Slc26a $4^{\Delta /+}$ mice, is $22 \mu \mathrm{M}$, whereas the $\mathrm{Ca}^{2+}$ concentration in Slc26a4 $4^{\Delta / \Delta}$ mice is $\sim 2 \mathrm{mM}$, which is higher by a factor of $\sim 100$ [34]. Whether the endocochlear potential contributes to the level of the endolymphatic $\mathrm{Ca}^{2+}$ concentration in Slc26a4 $4^{\Delta / \Delta}$ and Slc26a $4^{\Delta /+}$ mice is not known. It is conceivable that the elevated luminal $\mathrm{Ca}^{2+}$ concentration is a major factor that contributes to the degeneration of sensory hair cells [39]. Additional factors may be the luminal acidification, local cochlear hypothyroidism and the lack of the endocochlear potential. Similarly, marginal cells of stria vascularis degenerate after P15 and macrophages appear to invade stria vascularis after P30 in Slc26a4 ${ }^{\Delta / \Delta}$ mice [40]. Macrophages that accumulate in stria vascularis are strongly pigmented and give stria vascularis a dark appearance [6]. It is unclear whether pigmentation is inherent to macrophages or whether pigmentation is acquired by phagocytosis of melanin granules generated by intermediate cells of stria vascularis.

Secondary consequences of the lack of pendrin expression have also been observed in the vestibular labyrinth and include an increase in the endolymphatic $\mathrm{Ca}^{2+}$ concentration, which leads to the formation of giant otoconia $[6,38,39]$. Otoconia in the utricle and saccule of the vestibular labyrinth are normally no larger than $\sim 20 \mu \mathrm{m}$. Giant otoconia reach sizes of $\sim 200 \mu \mathrm{m}$. Giant otoconia have been reported in Slc26a4 $4^{\Delta / \Delta}$ mice as well as in Slc26a4 mutant mice $[6,39,44,49]$. Similar to the cochlea, the failure to lower the $\mathrm{Ca}^{2+}$ concentration in vestibular endolymph may be due to a lack of $\mathrm{Ca}^{2+}$ absorption via acid-sensitive Trvpv5 and Trpv6 $\mathrm{Ca}^{2+}$ channels $[34,38,50]$. Luminal acidification has been shown to inhibit transepithelial $\mathrm{Ca}^{2+}$ reabsorption in epithelial cells of the semicircular canals [38].

\section{Development of the inner ear with limited pendrin function}

The mouse model Slc26a $4^{\text {loop/loop }}$ was identified in a mutagenesis screen for neurosensory disorders and was found to contain a point mutation, S408F, that reduces the anion exchange activity of pendrin without affecting expression [49]. Interestingly, the reduction of pendrin activity results in a phenotype that is similar to the complete loss of pendrin expression seen in Slc26a4 $4^{\Delta / \Delta}$ mice. Slc26a4 $4^{\text {loop/loop }}$ mice do not acquire hearing, develop an enlargement of the cochlea, and form giant otoconia in the vestibular labyrinth. This finding points to the importance of sufficient pendrin function during development.

\section{Development of the inner ear without pendrin expression in the endolymphatic sac}

The mouse model Foxi1 $\%$ lacks expression of the transcription factor FOXI1, which controls the expression of pendrin in the endolymphatic sac but has no effect on the expression of pendrin in the cochlea or in the vestibular labyrinth [51]. Thus, Foxi1 $\%$ mice express pendrin in the cochlea and in the vestibular labyrinth but lack pendrin expression in 
the endolymphatic sac. The observations that Foxi $1^{\%}$ are deaf, have vestibular dysfunction, and develop prenatally an enlargement of the inner ear point to the importance of the endolymphatic sac for the development of the cochlea and the vestibular labyrinth.

\section{Development of the inner ear that lacks pendrin expression in the cochlea and the vestibular labyrinth}

The mouse model $\operatorname{Tg}(B 1-h P D S) S l c 26 a 4^{\Delta / \Delta}$ was developed to address the question of whether restoration of pendrin solely to the endolymphatic sac is sufficient to rescue inner ear function [52]. The model contains a transgene which consists of the promoter for human ATP6V1B1 driving the expression of human SLC26A4, formerly called $h P D S$. ATP6V1B1 codes for the B1-subunit of the $\mathrm{H}^{+}$ATPase, which is expressed in the endolymphatic sac but not in the cochlea or in the vestibular labyrinth [52]. Thus, $\operatorname{Tg}(B 1-h P D S) S l c 26 a 4^{\Delta / \Delta}$ mice express human pendrin in the endolymphatic sac but lack pendrin expression in the cochlea and the vestibular labyrinth. Most interestingly, hearing and balance were fully restored in $\operatorname{Tg}(B 1$ $h P D S$ SIc26a $4^{\Delta / \Delta}$ mice. This finding raises the possibility that a spatially limited therapy focused on the endolymphatic sac (a structure that is relatively remote from the cochlea) restores normal hearing and balance.

\section{Maintenance of hearing without pendrin}

A bi-transgenic mouse model, $\operatorname{Tg}[\mathrm{E}], \mathrm{Tg}[\mathrm{R}] \operatorname{Slc} 26 a 4^{\Delta / \Delta}$, was developed to address the question of whether pendrin is needed for the maintenance of hearing in a fully functional inner ear [53]. This model contains two transgenes, an effector transgene, $\mathrm{Tg}[\mathrm{E}]$, which consists of the murine promoter of Slc26a4 that mediates the expression of a transactivator and a responder transgene, $\operatorname{Tg}[\mathrm{R}]$, which contains a response-element for the doxycyclinebound transactivator to mediate the expression of murine Slc26a4. Both transgenes were crossed into the Slc26a4 ${ }^{\Delta / \Delta}$ line. In the presence of doxycycline, pendrin was expressed in the inner ear at natural times and natural sites. Omission or withdrawal of doxycycline prohibited expression or led to the rapid cessation of pendrin expression. Thus, pendrin expression could be controlled through doxycycline. Interestingly, loss of pendrin expression in a fully functional inner ear did not affect hearing [53]. This finding demonstrates that pendrin is required for the development but not for the maintenance of hearing.

\section{Pendrin expression is required during a critical time period during development}

The mouse model $\mathrm{Tg}[\mathrm{E}], \mathrm{Tg}[\mathrm{R}]$ Slc26a $44^{\Delta / \Delta}$ was used to determine the time period during which pendrin expression is required for normal cochlear development. The critical time period during which pendrin is needed for the development of normal hearing was between E16.5 and P2 [53]. The time period needed for the development of an uncompromised endocochlear potential appears to begin slightly earlier and to last slightly longer. This finding opens the prospect that a temporally limited therapy focused on the prenatal phase of development can restore normal hearing.

\section{Conclusions}

Studies in mouse models have provided tremendous insights into the role of pendrin in inner ear development. Moreover, studies of pendrin-related mouse models have revealed pathobiological mechanisms that may have broad implications beyond hearing loss associated with loss-of-function or hypo-functional mutations of SLC26A4. The concept 
that a temporally and spatially limited therapy may be sufficient to restore normal hearing provides an imperative to develop interventions that secure a life-time of normal hearing in children bearing mutations of SLC26A4.

\section{Acknowledgements}

The author thanks Dr. Daniel C. Marcus (Anatomy \& Physiology Department, Kansas State University, Manhattan, Kansas, USA) for critical review of this manuscript. The work was supported by Kansas State University and The National Institute on Deafness and Other Communication Disorders grant NIH-R01-DC012151.

\section{Conflict of Interests}

No conflict of interest.

\section{References}

- 1 Soleimani M, Greeley T, Petrovic S, Wang Z, Amlal H, Kopp P, Burnham CE: Pendrin: an apical $\mathrm{Cl}^{-} / \mathrm{OH}^{-} / \mathrm{HCO}_{3}{ }^{-}$ Exchanger in the Kidney Cortex. Am J Physiol Renal Physiol 2001;280:F356-F364.

2 Scott DA, Karniski LP: Human pendrin expressed in Xenopus laevis oocytes mediates chloride/formate exchange. Am J Physiol Cell Physiol 2000;278:C207-C211.

-3 Scott DA, Wang R, Kreman TM, Sheffield VC, Karniski LP: The Pendred syndrome gene encodes a chlorideiodide transport protein. Nat Genet 1999;21:440-443.

4 Royaux IE, Wall SM, Karniski LP, Everett LA, Suzuki K, Knepper MA, Green ED: Pendrin, encoded by the Pendred syndrome gene, resides in the apical region of renal intercalated cells and mediates bicarbonate secretion. Proc Natl Acad Sci U S A 2001;98:4221-4226.

5 Royaux IE, Suzuki K, Mori A, Katoh R, Everett LA, Kohn LD, Green ED: Pendrin, the protein encoded by the Pendred syndrome gene (PDS), is an apical porter of iodide in the thyroid and is regulated by thyroglobulin in FRTL-5 cells. Endocrinology 2000;141:839-845.

6 Wangemann P, Itza EM, Albrecht B, Wu T, Jabba SV, Maganti RJ, Lee JH, Everett LA, Wall SM, Royaux IE, Green ED, Marcus DC: Loss of KCNJ10 protein expression abolishes endocochlear potential and causes deafness in Pendred syndrome mouse model. BMC Medicine 2004;2:30

7 Nakao I, Kanaji S, Ohta S, Matsushita H, Arima K, Yuyama N, Yamaya M, Nakayama K, Kubo H, Watanabe M, Sagara H, Sugiyama K, Tanaka H, Toda S, Hayashi H, Inoue H, Hoshino T, Shiraki A, Inoue M, Suzuki K, Aizawa H, Okinami S, Nagai H, Hasegawa M, Fukuda T, Green ED, Izuhara K: Identification of pendrin as a common mediator for mucus production in bronchial asthma and chronic obstructive pulmonary disease. J Immunol 2008;180:6262-6269.

-8 Bidart JM, Lacroix L, Evain-Brion D, Caillou B, Lazar V, Frydman R, Bellet D, Filetti S, Schlumberger M: Expression of $\mathrm{Na}+/ \mathrm{I}-$ symporter and Pendred syndrome genes in trophoblast cells. J Clin Endocrinol Metab 2000;85:4367-4372.

9 Rillema JA, Hill MA: Prolactin regulation of the pendrin-iodide transporter in the mammary gland. Am J Physiol Endocrinol Metab 2003;284:E25-E28

10 Alesutan I, Daryadel A, Mohebbi N, Pelzl L, Leibrock C, Voelkl J, Bourgeois S, Dossena S, Nofziger C, Paulmichl M, Wagner CA, Lang F: Impact of bicarbonate, ammonium chloride, and acetazolamide on hepatic and renal SLC26A4 expression. Cell Physiol Biochem 2011;28:553-558.

11 Choi BY, Stewart AK, Madeo AC, Pryor SP, Lenhard S, Kittles R, Eisenman D, Jeffrey KH, Niparko J, Thomsen J, Arnos KS, Nance WE, King KA, Zalewski CK, Brewer CC, Shawker T, Reynolds JC, Butman JA, Karniski LP, Alper SL, Griffith AJ: Hypo-Functional SLC26A4 variants associated with nonsyndromic hearing loss and enlargement of the vestibular aqueduct: Genotype-phenotype correlation or coincidental polymorphisms? Hum Mutat 2009;30:599-608. 
-12 Pryor SP, Madeo AC, Reynolds JC, Sarlis NJ, Arnos KS, Nance WE, Yang Y, Zalewski CK, Brewer CC, Butman JA, Griffith AJ: SLC26A4/PDS genotype-phenotype correlation in hearing loss with enlargement of the vestibular aqueduct (EVA): evidence that Pendred syndrome and non-syndromic EVA are distinct clinical and genetic entities. J Med Genet 2005;42:159-165.

13 Zhou G, Gopen Q: Characteristics of vestibular evoked myogenic potentials in children with enlarged vestibular aqueduct. Laryngoscope 2011;121:220-225.

-14 Sugiura M, Sato E, Nakashima T, Sugiura J, Furuhashi A, Yoshino T, Nakayama A, Mori N, Murakami H, Naganawa S: Long-term follow-up in patients with Pendred syndrome: vestibular, auditory and other phenotypes. Eur Arch Otorhinolaryngol 2005;262:737-743.

15 Suzuki H, Oshima A, Tsukamoto K, Abe S, Kumakawa K, Nagai K, Satoh H, Kanda Y, Iwasaki S, Usami S: Clinical characteristics and genotype-phenotype correlation of hearing loss patients with SLC26A4 mutations. Acta Otolaryngol 2007;127:1292-1297.

16 Abe S, Usami S, Hoover DM, Cohn E, Shinkawa H, Kimberling WJ: Fluctuating sensorineural hearing loss associated with enlarged vestibular aqueduct maps to 7q31, the region containing the Pendred gene. Am J Med Genet 1999;82:322-328.

17 Fraser GR: Association of congenital deafness with goitre (Pendred's syndrome) a study of 207 families. Ann Hum Genet 1965;28. 201-249.

- 18 Yuan Y, You Y, Huang D, Cui J, Wang Y, Wang Q, Yu F, Kang D, Yuan H, Han D, Dai P: Comprehensive molecular etiology analysis of nonsyndromic hearing impairment from typical areas in China. J Transl Med 2009;7:79.

19 Park HJ, Shaukat S, Liu XZ, Hahn SH, Naz S, Ghosh M, Kim HN, Moon SK, Abe S, Tukamoto K, Riazuddin S, Kabra M, Erdenetungalag R, Radnaabazar J, Khan S, Pandya A, Usami SI, Nance WE, Wilcox ER, Riazuddin S, Griffith AJ: Origins and frequencies of SLC26A4 (PDS) mutations in east and south Asians: global implications for the epidemiology of deafness. J Med Genet 2003;40:242-248.

-20 Griffith AJ, Wangemann P: Hearing loss associated with enlargement of the vestibular aqueduct: Mechanistic insights from clinical phenotypes, genotypes, and mouse models. Hear Res 2011;281:11-17.

-21 Ito T, Choi BY, King KA, Zalewski CK, Muskett J, Chattaraj P, Shawker T, Reynolds JC, Butman JA, Brewer CC, Wangemann P, Alper SL, Griffith AJ: SLC26A4 genotypes and phenotypes associated with enlargement of the vestibular aqueduct. Cell Physiol Biochem 2011;28:545-552.

22 Ito T, Muskett J, Chattaraj P, Choi BY, Lee KY, Zalewski C, King KA, Li X, Wangemann P, Shawker T, Brewer CC, Alper SL, Griffith AJ: SLC26A4 mutation testing for hearing loss associated with enlargement of the vestibular aqueduct. World J Otorhinolaryngology 2013;3:26-34.

23 Mansour SL, Schoenwolf GC: Morphogenesis of the inner ear; in Kelley MW, Wu D, Popper AN, Fay RR (eds): Springer Handbook of Auditory Research: Development of the inner ear. Springer 2005, pp. 43-84.

24 Cheung CY, Brace RA: Amniotic fluid volume and composition in mouse pregnancy. J Soc Gynecol Investig 2005;12;558-562.

25 Kim HM, Wangemann P: Failure of fluid absorption in the endolymphatic sac initiates cochlear enlargement that leads to deafness in mice lacking pendrin expression. PLoS One 2010;5:e14041-.

26 Li X, Zhou F, Marcus DC, Wangemann P: Endolymphatic $\mathrm{Na}^{+}$and $\mathrm{K}^{+}$concentrations during cochlear growth and enlargement in mice lacking Slc26a4/pendrin. PLoS One 2013;8:e65977

-27 Cantos R, Cole LK, Acampora D, Simeone A, Wu DK: Patterning of the mammalian cochlea. Proc Natl Acad Sci U S A 2000;97:11707-11713.

28 Geleoc GS, Holt JR: Developmental acquisition of sensory transduction in hair cells of the mouse inner ear. Nat Neurosci 2003;6:1019-1020.

29 Lelli A, Asai Y, Forge A, Holt JR, Geleoc GS: Tonotopic gradient in the developmental acquisition of sensory transduction in outer hair cells of the mouse cochlea. J Neurophysiol 2009;101:2961-2973.

30 Nordemar H: Postnatal development of the vestibular sensory epithelium in the mouse. Acta Otolaryngol 1983;96:447-456.

-31 Desmadryl G, Sans A: Afferent innervation patterns in crista ampullaris of the mouse during ontogenesis. Brain Res Dev Brain Res 1990;52:183-189.

-32 Steel KP, Barkway C: Another role for melanocytes: their importance for normal stria vascularis development in the mammalian inner ear. Development 1989;107:453-463.

-33 Yamasaki M, Komune S, Shimozono M, Matsuda K, Haruta A: Development of monovalent ions in the endolymph in mouse cochlea. ORL J Otorhinolaryngol Relat Spec 2000;62:241-246. 
34 Wangemann P, Nakaya K, Wu T, Maganti R, Itza EM, Sanneman J, Harbidge D, Billings S, Marcus DC: Loss of cochlear HCO3- secretion causes deafness via endolymphatic acidification and inhibition of $\mathrm{Ca}^{2+}$ reabsorption in a Pendred syndrome mouse model. Am J Physiol Renal Physiol 2007;292:1345-1353.

-35 Wangemann P: Supporting sensory transduction: cochlear fluid homeostasis and the endocochlear potential. J Physiol 2006;576:11-21.

-36 Royaux IE, Belyantseva IA, Wu T, Kachar B, Everett LA, Marcus DC, Green ED: Localization and functional studies of pendrin in the mouse inner ear provide insight about the etiology of deafness in pendred syndrome. J Assoc Res Otolaryngol 2003;4:394-404.

-37 Kim HM, Wangemann P: Epithelial cell stretching and luminal acidification lead to a retarded development of stria vascularis and deafness in mice lacking pendrin. PLoS One 2011;6:e17949.

- 38 Nakaya K, Harbidge DG, Wangemann P, Schultz BD, Green E, Wall SM, Marcus DC: Lack of pendrin HCO3transport elevates vestibular endolymphatic [Ca2+] by inhibition of acid-sensitive TRPV5 and TRPV6. Am J Physiol Renal Physiol 2007;292:1314-1321.

- 39 Everett LA, Belyantseva IA, Noben-Trauth K, Cantos R, Chen A, Thakkar SI, Hoogstraten-Miller SL, Kachar B, Wu DK, Green ED: Targeted disruption of mouse Pds provides insight about the inner-ear defects encountered in Pendred syndrome. Hum Mol Genet 2001;10:153-161.

40 Jabba SV, Oelke A, Singh R, Maganti RJ, Feming S, Wall SM, Everett LA, Green ED, Wangemann P: Macrophage invasion contributes to degeneration of stria vascularis in Pendred syndrome mouse model. BMC Med 2006;4:37.

41 Singh R, Wangemann P: Free radical stress mediated loss of Kcnj10 protein expression in stria vascularis contributes to deafness in Pendred syndrome mouse model. Am J Physiol Renal Physiol 2008;294:F139-F148

42 Wangemann P, Jabba SV, Singh R, Wu T, Oelke A, Gollapudi ASB, Marcus DC: Deafness in Pendred Syndrome is related to free radical stress in stria vascularis. Proc Meniere's Meeting 2005;5:36-41.

-43 Wangemann P, Kim HM, Billings S, Nakaya K, Li X, Singh R, Sharlin DS, Forrest D, Marcus DC, Fong P: Developmental delays consistent with cochlear hypothyroidism contribute to failure to develop hearing in mice lacking Slc26a4/pendrin expression. Am J Physiol Renal Physiol 2009;297:F1435-F1447

44 Lu YC, Wu CC, Shen WS, Yang TH, Yeh TH, Chen PJ, Yu IS, Lin SW, Wong JM, Chang Q, Lin X, Hsu CJ: Establishment of a Knock-In Mouse Model with the SLC26A4 c.919-2A>G Mutation and Characterization of Its Pathology. PLoS One 2011;6:e22150-

45 Wangemann P, Shen Z, Liu J: $\mathrm{K}^{+}$-induced stimulation of $\mathrm{K}^{+}$secretion involves activation of the IsK channel in vestibular dark cells. Hear Res 1996;100:201-210.

46 Wangemann P, Liu J, Marcus DC: Ion transport mechanisms responsible for $\mathrm{K}^{+}$secretion and the transepithelial voltage across marginal cells of stria vascularis in vitro. Hear Res 1995;84:19-29.

47 Unsold B, Kerst G, Brousos H, Hubner M, Schreiber R, Nitschke R, Greger R, Bleich M: KCNE1 reverses the response of the human $\mathrm{K}^{+}$channel KCNQ1 to cytosolic $\mathrm{pH}$ changes and alters its pharmacology and sensitivity to temperature. Pflugers Arch 2000;441:368-378.

48 Marcus DC, Wu T, Wangemann P, Kofuji P: KCNJ10 (Kir4.1) potassium channel knockout abolishes endocochlear potential. Am J Physiol Cell Physiol 2002;282:C403-C407

-49 Dror AA, Politi Y, Shahin H, Lenz DR, Dossena S, Nofziger C, Fuchs H, Hrabe dA, Paulmichl M, Weiner S, Avraham KB: Calcium oxalate stone formation in the inner ear as a result of an Slc26a4 mutation. J Biol Chem 2010;285;21724-21735.

50 Yamauchi D, Nakaya K, Raveendran NN, Harbidge DG, Singh R, Wangemann P, Marcus DC: Expression of epithelial calcium transport system in rat cochlea and vestibular labyrinth. BMC Physiol 2010;10:1.

-51 Hulander M, Kiernan AE, Blomqvist SR, Carlsson P, Samuelsson EJ, Johansson BR, Steel KP, Enerback S: Lack of pendrin expression leads to deafness and expansion of the endolymphatic compartment in inner ears of Foxi1 null mutant mice. Development 2003;130:2013-2025.

52 Li X, Sanneman JD, Harbidge DG, Zhou F, Ito T, Nelson R, Picard N, Chambrey R, Eladari D, Miesner T, Griffith AJ, Marcus DC, Wangemann P: SLC26A4 targeted to the endolymphatic sac rescues hearing and balance in Slc26a4 mutant mice. PLoS Genet 2013;9:e1003641.

53 Choi BY, Kim HM, Ito T, Lee KY, Li X, Monahan K, Wen Y, Wilson E, Kurima K, Saunders TL, Petralia RS, Wangemann P, Friedman TB, Griffith AJ: Mouse model of enlarged vestibular aqueducts defines temporal requirement of Slc26a4 expression for hearing acquisition. J Clin Invest 2011;121:4516-4525. 